\title{
STUDI EXPERIMEN PENGARUH KANDUNGAN MINYAK LUMAS TERHADAP KERATAAN MAIN BEARING MAIN ENGINE MV. BNI CASTOR
}

\author{
Rudi Saman ${ }^{1)}$ Abdul Basir ${ }^{2)}$ Rukmini $^{3)}$ \\ Politeknik IImu Pelayaran Makassar \\ Jalan Tentara Pelajar No. 173 Makassar, Kode pos. 90172 \\ Telp. (0411) 361697975; Fax (0411) 3628732 \\ E-mail: pipmks@pipmakassar.com
}

\begin{abstract}
ABSTRAK
Penelitian ini bertujuan mengetahui pengaruh kandungan minyak lumas terhadap kerataan main bearing main engine. Fungsi pelumasan main bearing yaitu untuk megurangi gesekan pada main bearing dan crankshaft agar tidak terjadi kontak langsung antara kedua bagian yang dapat menyebabkan keausan pada kedua permukaan yang dapat mempengaruhi kinerja main engine. Lokasi penelitian ini berada dikamar mesin Kapal MV. BNI Castor, milik PT. Bahtera Niaga Internasional. Sistem pelumasan pada MV. BNI Castor menggunakan jenis pelumasan carter basah dan merk minyak pelumas adalah Meditran SMX SAE 40. Hasil penelitian menunjukkan bahwa kurangnya penanganan atau perawatan pada bantalan utama dan akhirnya menyebabkan daya kerja bantalan tidak maksimal dalam menjaga tingkat keseimbangan putaran poros.
\end{abstract}

Kata Kunci : Minyak lumas dan main bearing

\section{PENDAHULUAN}

Minyak lumas adalah zat cair atau benda cair yang digunakan sebagai bahan pelumasan dalam suatu mesin. Minyak lumas main engine harus seimbang kandungan nilai basa dan nilai asam sebagai media yang dapat menetralkan kerusakan permukaan dan kerusakan isi bagian dalam pada bagian yang terkontaminasi langsung minyak lumas baik yang bergerak maupun yang diam terutama minyak lumas sebagai media pelumasan main engine. Pelumasan adalah zat kimia yang umumnya cairan yang diberikan diantara dua benda bergerak untuk mengurangi gaya gesek dengan mempertahankan viscos dan valensi kimia yang dikandungnya tetap stabil.

Main bearing merupakan elemen mesin yang memerlukan perhatian khusus untuk kontinitas pelumasnya bila main engine sedang beroperasi. Kerusakan yang dapat ditimbulkan pada main bearing seperti metal hancur, adanya goresan atau permukaan tidak rata, temperatur bantalan 
meningkat, kerja mesin tidak maksimal. Apabila dibiarkan terus menerus berlangsung daya kerja mesin akan turun.

Kandungan minyak lumas berperan penting mengurangi resiko-resiko kerusakan main bearing main engine pelumasannya berfungsi ganda sebagai pendingin dan pemisah kotoran hasil gesekan kemudian menahan beban momen dari gaya- gaya yang muncul pada saat main engine dioperasikan.

Menurut Junaid (2005), permasalahannya mirip sama dengan permasalahan yang akan penulis teliti yaitu kerusahan main bearing saat berlayar dari Singapore menuju Jepan, main engine tiba-tiba mati mendadak, setelah diperiksa system minyak lumas dan volume dalam carter normal, namun setelah diambil sampel dan diuji di laboratorium minyak $\mathrm{pH}$ lumas melebih standar di atas 13 , kondisi inilah yang merusak hingga berlubang main bearing dan mempengaruhi poros engkol.

Sesuai dengan permasalahan pada latar belakang dan kenyataan tersebut di atas penulis tarik untuk mengangkat menjadi sebuah penelitian "studi experimen pengaruh kandungan minyak lumas terhadap kerataan main bearing main engine mv. Bni castor'”

\section{TINJAUAN PUSTAKA}

A. Main Bearing

Menurut V.L.Maleev (1986:91) Operasi dan Pemeliharaan Mesin Diesel. Main bearing digunakan pada bagian mesin yang meneruskan gaya atau beban dari bagian yang bergerak kepada bagian yang stasioner sehingga mendukung bagian yang bergerak. Permukaan yang bersinggungan di bawah tekanan disebut permukaan bantalan.

Main bearing adalah bagian penting dalam sebuah mesin, minyak dan permesinan lain yang dihubungkan denganya.Tujuan dari suatu Bantalan adalah untuk menopang suatu beban tetapi 
tetap memberikan kemungkinan terjadinya gerakan relatif di antara dua permukaan element dalam sebuah mesin.

Pemahaman yang baik dari fungsi berbagai main bearing sangat penting untuk mempertahankan performa mesin karena main bearing berperan penting dalam kelancaran putaran dari crankshaft.

\section{B. Bahan-Bahan Bantalan}

Bahan-bahan dari perpaduan Bantalan utama mesin induk. Pada beban bantalan yang lebih tinggi harus digunakan material bantalan yang lebih keras. Misalnya timah hitam-brons atau kuningan-timah hitam. bahan trimetal modern terdiri dari sebuah piringan baja tipis yang dilapisi dengan kuningan timah atau timah hitam brons. (P.Van Maanen. 1986).

a. Bahan-Bahan bantalan (Robert L.Mott) adalah:

1) Perunggu coran

Nama perunggu mengacu pada beberapa campuran logam dari beberapa tembaga timah, timbale, seng atau almunium, baik sendiri-sendiri atau dalam kombinasi. Perunggu timbale mengandung 25\%-35\% timbal sehingga memiliki sifat mampu benam yang baik dan tahan terhadap himpitan dalam kondisi batas.

2) Babit

Babit (baja putih) berbahan dasar timbal atau berbahan dasar timah yang secara nominal memiliki $80 \%$ logam induk, berbagai komposisi paduan tembaga dan antimony dapat diolah sifat-sifatnya untuk memenuhi suatu aplikasi khusus. Bantalan utama terdiri atas bagian bawah dan atas yang terbuat dari besi tuang atau baja tuang yang dilapisi dengan babit (white metal). 
2) Almunium

Almunium memiliki kekuatan tertinggi yang umumnya digunakan sebagai bahan bantalan. Almunium digunakan dalam beberapa aplikasi dalam mesin, pompa, dan pesawat terbang. Kekerasan yang tinggi dari bahan almunium menghasilkan sifat mampu benam buruk,sehingga memerlukan pelumas yang bersih.

3) Seng

Bantalan yang terbuat dari paduan seng memberikan perlindungan yang baik tanpa suplai minyak pelumas yang terus-menerus, meskipun akan beroperasi dengan sangat baik jika di lumasi. Ketika beroperasi pada tap-tap dari baja,lapisan tipis dari bahan seng yang lebih lunak akan berpindah ke baja sehingga melindunginya dari aus dan kerusakan.

b. Bahan Crankshaft

Bahan crankshaft (S.H Frederik dan H. Capper) dalam bukunya Materials For Marchinery yaitu baja-karbon magnitude yang diperoleh dari hasil dapur tinggi dalam tungku pembakaran atau listrik pada suhu 1.500 c, dari hasil akhir yang diperoleh biasanya ditambahkan sedikit jumlah silikon dan almunium atau titanium.

C. Gambaran Umum Syarat Dari Suatu Bantalan

Persyaratan bahan untuk bantalan harus memenuhi (SularsoKiyokatsu Suga, Dasar Perencanaan dan Pemilihan Elemen Mesin) :

1. Mempunyai kekuatan cukup (tahan beban dan kelelahan)

2. Dapat menyesuaikan diri terhadap lenturan poros yang tidak terlalu besar atau terhadap perubahan bentuk yang kecil

3. Mempunyai sifat anti las (tidak dapat menempel) terhadap poros jika terjadi kontak antara logam dan logam.

4. Cukup tahan aus (wear). 
5. Dapat membenamkan kotoran atau debu kecil yang terkurung didalam bantalan

6. Tidak terlalu terpengaruh oleh temperature

7. Sangat tahan karat.

D. Gambaran Umum Faktor Yang Mempengaruhi Kerja Main Bearing

a. Gesekan

Gesekan adalah gaya yang berarah melawan gerak benda atau arah benda akan bergerak. Gaya gesek muncul apabila dua buah benda bersentuhan. gaya gesekan akan semakin berat jika permukaan benda yang saling bergesekan semakin kasar, semakin berat, dan luas permukaan benda tersebut, (sumber: id.wikipedia.org). Menurut Maleev (1991) dalam bukunya "diesel engine operations and maintenance", Mengemukakan bahwa bagaimanapun halusnya dan tepatnya permukaan logam dapat dilihat atau dirasakan, tetapi sebenarnya tidak rata melainkan terdiri atas titik yang tinggi dan rendah, kalau dilihat dengan pembesaran yang kuat maka penampang melintangnya seperti terlihat pada gambar diatas. kalau suatu permukaan meluncur diatas suatu permukaan yang lain dan suatu gaya menekannya terhadap permukaan yang lain tersebut, maka titik yang tinggi pada kedua permukaan akan saling mengunci dan menghambat gerakan relatif.

b.Pelumas

Menurut Arisandi dkk, 2012 minyak lumas adalah zat cair atau benda cair yang digunakan sebagai bahan pelumasan dalam suatu mesin. Semua elemen mesin yang terbuat dari logam akan bergerak relatif antara satu dengan lainnya dapat mengalami hambatan yang besar karena gesekan permukaan. Karena hal tersebut, fungsi pelumas menjadi sangat penting. Dengan pelumasan dapat dihindari kontak langsung dari dua bagian logam mesin yang bergesekan.fungsi pelumasan adalah sebagai berikut: 
1. Mengurangi gesekan yang timbul antar komponen mesin sehingga pergerakan komponen mesin menjadi lebih ringan.

2. Menyerap panas yang timbul karena pergesekan antara komponen-komponen mesin, hal ini menguntungkan karena komponen mesinterhindar dari overheating atau panas berlebih.

3. Khusus pada pelumasan di silinder akan memperbaiki kerapatan antara torak dan silinder.

4. Mencegah abrasi dan korosi komponenkomponen mesin.

Adapun karakteristik minyak lumas menurut Rizqon Fajar dan Siti Yubaidah, 2007 (Penentuan Kualitas Pelumasan Mesin) yaitu :

1. Viscosity

2. Viscosity Index

3. Flash Point

4. Pour Point

5. Total Base Number (TBN)

6. Carbon Residue

7. Density

8. Emulsification dan Demulsibility

\section{METODE PENELITIAN}

Penelitian ini dilakukan selama melaksanakan prektek laut di kapal Mv. Bni Castor dari 30 september 2017 - 16 Oktober 2018.

Dalam rancangan penelitian dalam bentuk eksperimen ini langkahlangkah yang dilakukan adalah kajian pustaka.

\section{HASIL PENELITIAN DAN PEMBAHASAN}

\section{Data penelitian}

1. Data spesifikasi main engine

a. Objek penelitian yang penulis lakukan pada main engine di MV BNI CASTOR adalah sebagai berikut : 
Engine Configuration

Bore

Stroke

Displacement

Compression Ratio

Rotation (from flywheel end)

Lube System

Length

Width

Height

Weight Net Dry (Basic Operating
: V-16, 4-Stroke-Cycle Diesel

: $170 \mathrm{~mm}$ (6.7 in)

: $215 \mathrm{~mm}$ (8.5 in)

:Turbocharged Aftercooled

$: 14.7: 1$

: Counterclockwise

: (refill) 807 L (852 qt)

: $3278 \mathrm{~mm}$ (129.1 in)

:1530 mm (60.2 in)

:2062 mm (81.2 in)

: $7840 \mathrm{Kg}$ (17284 lb)Engine WithoutOptional

b. Data spesifikasi minyak lumas Meditran SMX SAE 40

Tabel 1 Data spesifikasi minyak lumas.

\begin{tabular}{|c|c|c|}
\hline No & Typhical Characteristics & Result \\
\hline 1 & No. SAE & $15 \mathrm{~W}-40$ \\
\hline 2 & Density at $15^{\circ} \mathrm{C}(\mathrm{kg} / \mathrm{L})$ & 0,8860 \\
\hline & Viscosity kinematic, at $40^{\circ} \mathrm{C}, \mathrm{CST}$ \\
3 & at $100^{\circ}, \mathrm{cST}$ & 112,01 \\
\hline 4 & Viscosity index & 14,99 \\
\hline 5 & Flash point $\left({ }^{\circ} \mathrm{C}\right)$ & 139 \\
\hline 6 & Pour point $\left({ }^{\circ} \mathrm{C}\right)$ & 216 \\
\hline 7 & Total base number $(\mathrm{mg} \mathrm{KOH} / \mathrm{G})$ & -24 \\
\hline 8 & Apparent viscosity at $-20^{\circ} \mathrm{C}, \mathrm{cps}$ & 11,35 \\
\hline
\end{tabular}

Sumber : Pertamina oil specification 
c. Data statistik main bearing main engine

Adapun spesifikasi gambaran umum objek penelitian bantalan utama mesin induk meliputi :

$\begin{array}{ll}\text { Diameter bantalan } & : 28,19 \mathrm{~cm} \\ \text { Tebal bantalan } & : 1,02 \mathrm{~cm} \\ \text { Bahan bantalan } & : \text { Perunggu coran, Babit (baja } \\ & \text { putih), Almunium, Seng. } \\ & : 720^{\circ}-900^{\circ} \mathrm{c} \text { atau } 100^{\circ} \\ \text { Temperatur max } & : 30 \mathrm{bar} \\ \text { Tekanan (presure) } & : 28,09 \mathrm{~cm} \\ \text { Diameter crankshaft } & : \text { Baja karbon magnitude } \\ \text { Bahan crankshaft } & \text { ditambahkan almunium atau } \\ & \text { titanium, Baja krom nikel. }\end{array}$

\section{Analisa data}

Spss statistic product service solutions) adalah program aplikasi yang memiliki kemampuan analisa statistic cukup tinggi serta system managemen data pada lingkungan grafiki dengan menggunakan menumenu deskriktif dan kotak kotak dialog sederhana sehingga mudah dipahami secara pengoperasian

1. dengan program spss

a. Analisa data tekanan in Pompa, Saringan dan kecepatan L.O 
Tabel 2 analisa tekanan in (masuk) pada pompa , saringan dan kecepatan L.O

\section{Descriptive Statistics}

\begin{tabular}{|c|c|c|c|c|c|}
\hline & $\mathrm{N}$ & Minimum & Maximum & Mean & $\begin{array}{c}\text { Std. } \\
\text { Deviaton }\end{array}$ \\
\hline Normal & 3 & 30.00 & 30.00 & 30.0000 & .00000 \\
Upnormal & 3 & 30.00 & 34.50 & 32.1667 & 2.25462 \\
Alarm & 3 & 2.52 & 20.00 & 8.3467 & 10.09208 \\
Mati & 3 & .38 & 17.00 & 5.9200 & 9.59556 \\
Setelah & 3 & 29.30 & 31.00 & 30.1000 & 8.5440 \\
Perbaikan & 3 & & & & \\
Valid N & & & & & \\
(Listwise) & & & & & \\
\hline
\end{tabular}

Sumber : hasil proses olah data dengan program spss -2018

Penjelasan :

- Rata - rata nilai normal adalah 30.00 dengan standard deviasi .00000 dengan jumlah pengamatan 3

- Rata -rata nilai upnormal adalah dengan 32.16 standard deviasi 2.25462 dengan jumlah pengamatan 3

- Rata - rata nilai alarm adalah 8.34 dengan standard deviasi 10.09208 dengan jumlah pengamatan 3

- Rata - rata nilai mati adalah 5.92 dengan standard deviasi 9.59556 dengan jumlah pengamatan 3

- Rata - rata nilai setelah perbaikan adalah 30.10 dengan standard deviasi .85440 dengan jumlah pengamatan 3 
Grafik 1. analisa tekanan in (masuk) pada pompa , saringan dan kecepatan L.O

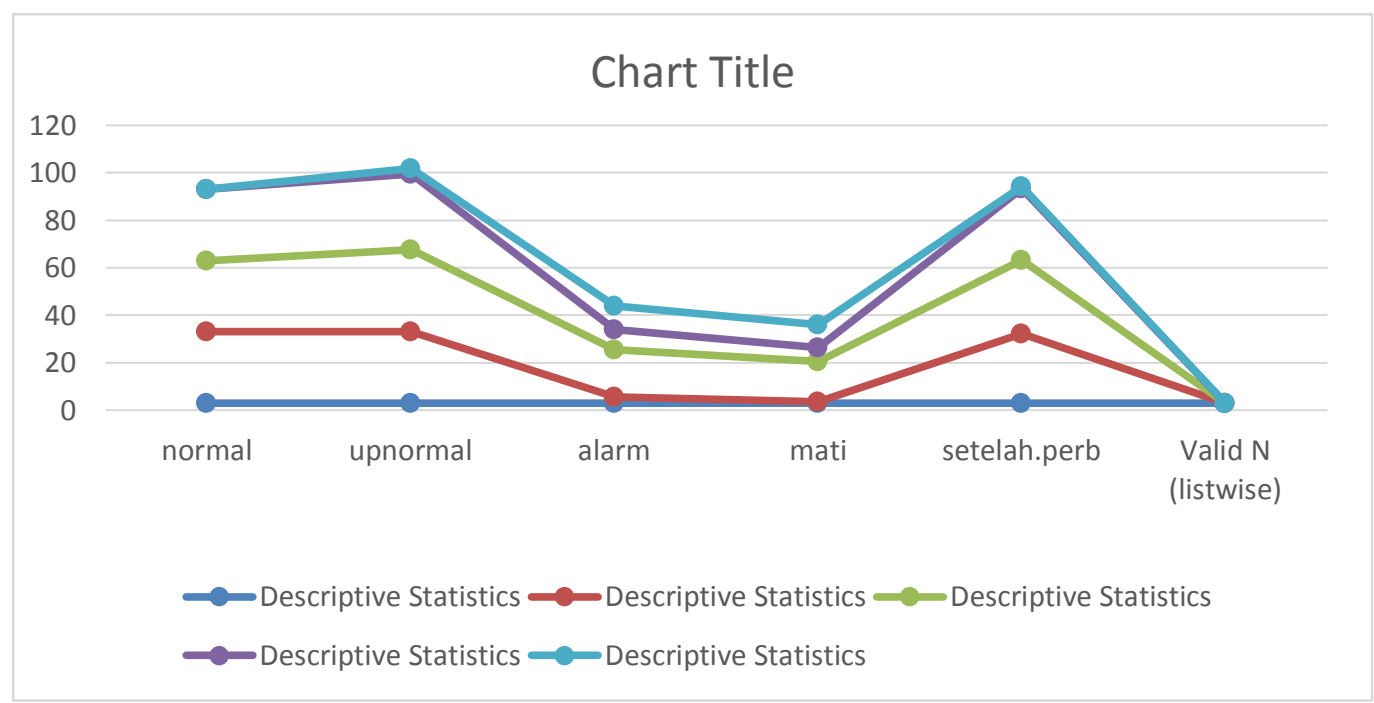

b. Analisa data tekanan out Pompa, Saringan dan kecepatan L.O

Tabel 3 analisa tekanan out (keluar) pada pompa , saringan dan

kecepatan L.O

Descriptive Statistics

\begin{tabular}{|l|c|c|c|c|c|}
\hline & $\mathrm{N}$ & Minimum & $\begin{array}{c}\text { Maximu } \\
\mathrm{m}\end{array}$ & Mean & Std. Deviation \\
\hline Normal & 3 & 34.50 & 45.00 & 38.0000 & 6.06218 \\
Upnormal & 3 & 3.70 & 39.70 & 27.5000 & 20.61359 \\
Alarm & 3 & 3.00 & 23.00 & 9.6667 & 11.54701 \\
Mati & 3 & .46 & 19.60 & 6.8400 & 11.05048 \\
setelah.perb & 3 & 33.20 & 46.00 & 38.8000 & 6.54828 \\
Valid N & 3 & & & & \\
(listwise) & & & & & \\
\hline
\end{tabular}

Sumber : hasil proses olah data dengan program spss -2018 


\section{Penjelasan :}

- Rata - rata nilai normal adalah 38.00 dengan standard deviasi 6.06218 dengan jumlah pengamatan 3

- Rata -rata nilai upnormal adalah 27.50 dengan standard deviasi 20.61359 dengan jumlah pengamatan 3

- Rata - rata nilai alarm 9.66 adalah dengan standard deviasi 11.54701 dengan jumlah pengamatan 3

- Rata - rata nilai mati 6.84 adalah dengan standard deviasi 11.05048 dengan jumlah pengamatan 3

- Rata - rata nilai setelah perbaikan adalah 38.80 dengan standard deviasi 6.54828 dengan jumlah pengamatan 3

Grafik 2 analisa tekanan out (keluar) pada pompa, saringan dan kecepatan L.O

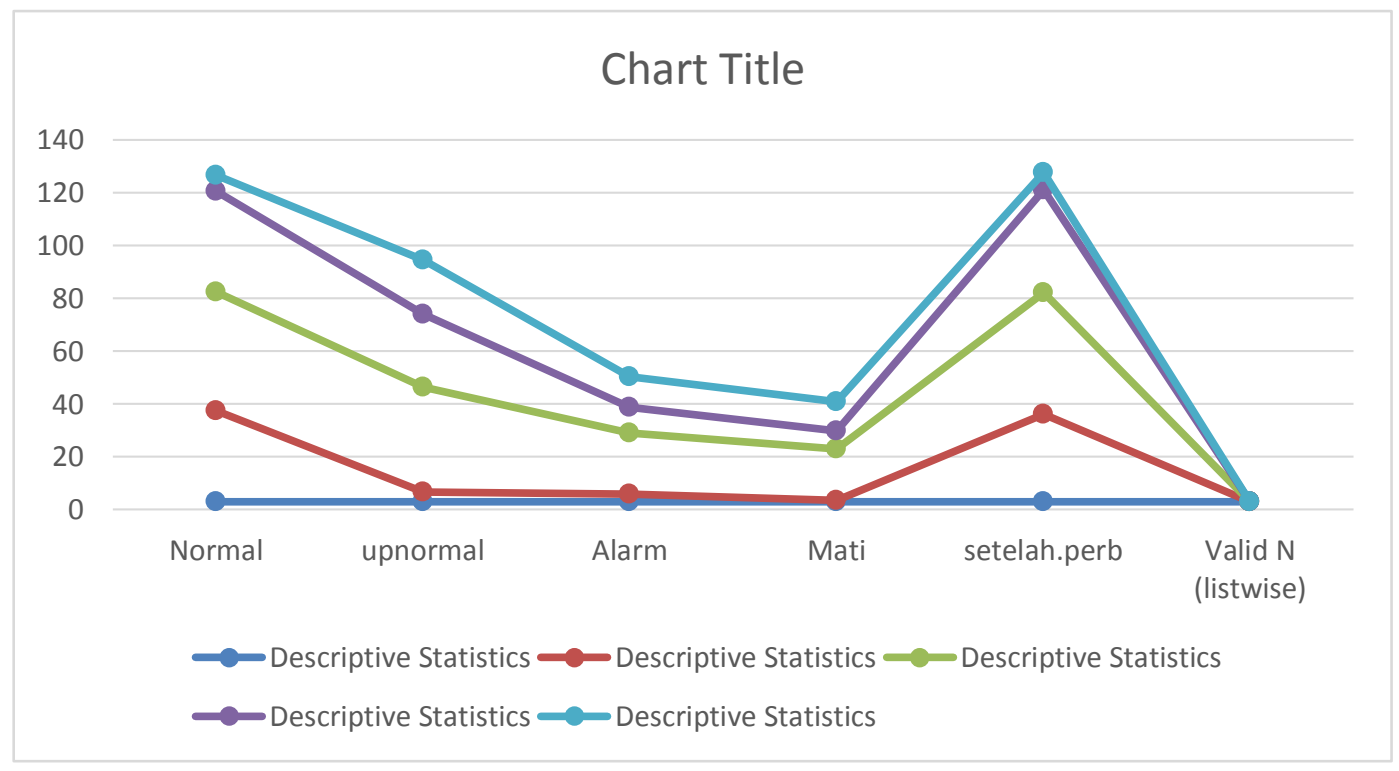


c. Analisa data temperature in Pompa, Saringan dan kecepatan L.O

Tabel 4 analisa tekanan in (masuk) pada pompa, saringan dan kecepatan L.O

\section{Descriptive Statistics}

\begin{tabular}{|l|c|c|c|c|c|}
\hline & $\mathrm{N}$ & Minimum & $\begin{array}{c}\text { Maximu } \\
\mathrm{m}\end{array}$ & Mean & Std. Deviation \\
\hline Normal & 3 & 1.28 & 30.00 & 12.5267 & 15.33910 \\
Upnormal & 3 & 1.15 & 26.00 & 10.7300 & 13.36648 \\
Alarm & 3 & 35.00 & 39.60 & 36.5333 & 2.65581 \\
Mati & 3 & 38.00 & 45.50 & 40.5000 & 4.33013 \\
setelah.perb & 3 & 1.38 & 29.00 & 12.1400 & 14.78593 \\
Valid N & 3 & & & & \\
(listwise) & & & & & \\
\hline
\end{tabular}

Sumber : hasil proses olah data dengan program spss -2018

Penjelasan :

- Rata - rata nilai normal adalah 12.52 dengan standard deviasi 15.33910 dengan jumlah pengamatan 3

- Rata -rata nilai upnormal adalah 10.73 dengan standard deviasi 13.36648 dengan jumlah pengamatan 3

- Rata - rata nilai alarm adalah 36.53 dengan standard deviasi 2.65581 dengan jumlah pengamatan 3

- Rata - rata nilai mati 40.50 adalah dengan standard deviasi 4.33013 dengan jumlah pengamatan 3

- Rata - rata nilai setelah perbaikan adalah 12.14 dengan standard deviasi 14.78593 dengan jumlah pengamatan 3 
Grafik 3 analisa temperature in (masuk) pada pompa, saringan dan kecepatan L.O

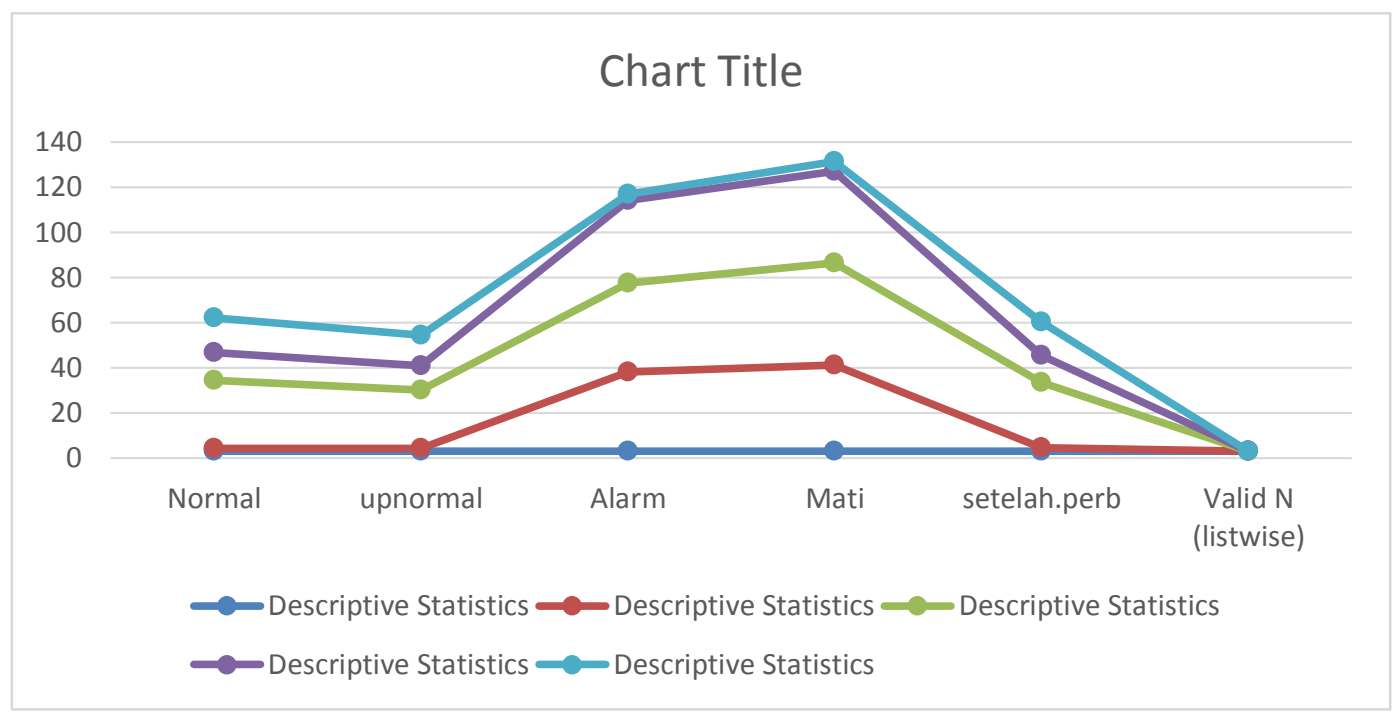

d. Analisa data temperature out Pompa, Saringan dan kecepatan L.O Tabel 5 analisa tekanan out (keluar) pada pompa , saringan dan kecepatan L.O

\section{Descriptive Statistics}

\begin{tabular}{|l|c|c|c|c|c|}
\hline & $\mathrm{N}$ & Minimum & Maximum & Mean & Std. Deviation \\
\hline Normal & 3 & 11.70 & 41.20 & 27.0000 & 14.78073 \\
Upnormal & 3 & 1.33 & 29.90 & 12.3433 & 15.36791 \\
Alarm & 3 & 40.00 & 44.90 & 41.6333 & 2.82902 \\
Mati & 3 & 43.00 & 51.80 & 45.9333 & 5.08068 \\
setelah.perb & 3 & 1.58 & 34.30 & 14.1933 & 17.60006 \\
Valid N & 3 & & & & \\
(listwise) & & & & & \\
\hline
\end{tabular}

Sumber : hasil proses olah data dengan program spss -2018 
Penjelasan :

- Rata - rata nilai normal adalah 27.00 dengan standard deviasi 14.78073 dengan jumlah pengamatan 3

- Rata -rata nilai upnormal adalah 12.34 dengan standard deviasi 15.36791dengan jumlah pengamatan 3

- Rata - rata nilai alarm adalah 41.63 dengan standard deviasi 2.82902 dengan jumlah pengamatan 3

- Rata - rata nilai mati 45.93 adalah dengan standard deviasi 5.08068 dengan jumlah pengamatan 3

- Rata - rata nilai setelah perbaikan adalah 14.19 dengan standard devias 17.60006 dengan jumlah pengamatan 3

Grafik 4 analisa temperature out (keluar) pada pompa, saringan dan kecepatan L.O

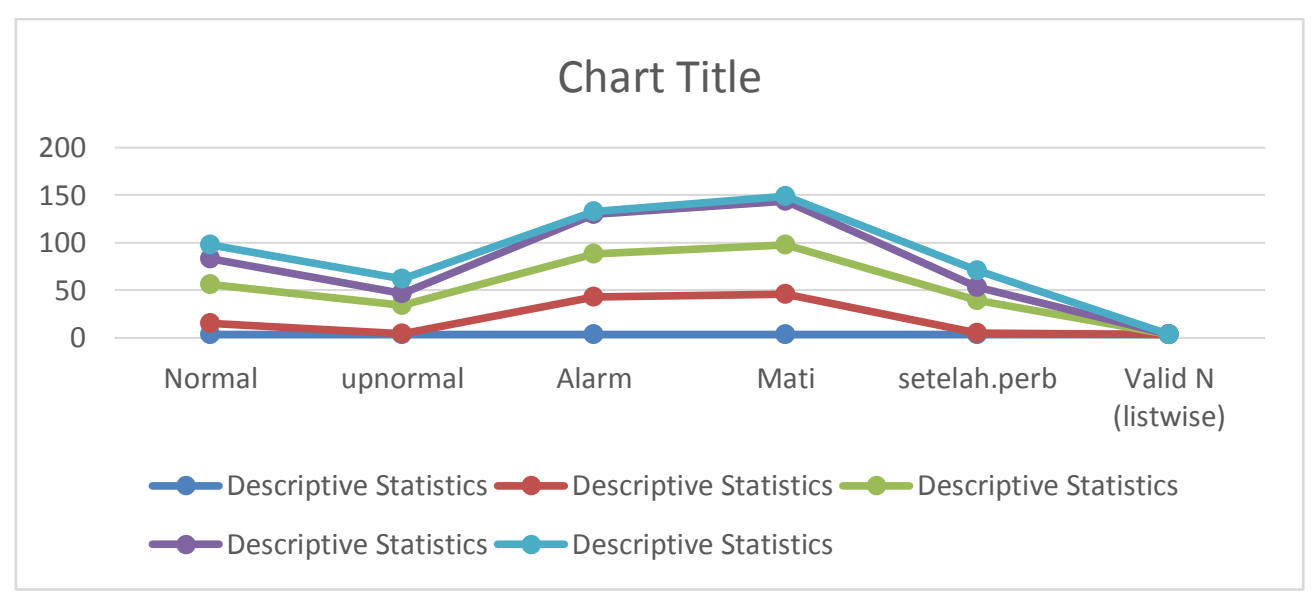


e. Analisa data debit aliran in Pompa, Saringan dan kecepatan L.O

Tabel 5 analisa debit aliran in (masuk) pada pompa , saringan dan

kecepatan L.O

Descriptive Statistics

\begin{tabular}{|l|c|c|c|c|c|}
\hline & $\mathrm{N}$ & Minimum & Maximum & Mean & Std. Deviation \\
\hline normal & 3 & 58.00 & 434.00 & 184.0000 & 216.50866 \\
upnormal & 3 & 29.00 & 55.70 & 42.6333 & 13.35902 \\
Alarm & 3 & 10.60 & 37.40 & 28.4667 & 15.47299 \\
Mati & 3 & 1.10 & 35.30 & 23.9000 & 19.74538 \\
setelah.perb & 3 & 42.40 & 66.84 & 56.0800 & 12.47891 \\
Valid N & 3 & & & & \\
(listwise) & & & & & \\
\hline
\end{tabular}

Sumber : hasil proses olah data dengan program spss -2018

Penjelasan :

- Rata - rata nilai normal adalah 184.00 dengan standard deviasi 216.50866 dengan jumlah pengamatan 3

- Rata -rata nilai upnormal adalah 42.63 dengan standard deviasi 13.35902 dengan jumlah pengamatan 3

- Rata - rata nilai alarm adalah 28.46 dengan standard deviasi 15.47299 dengan jumlah pengamatan 3

- Rata - rata nilai mati adalah 23.90 dengan standard deviasi 19.74538 dengan jumlah pengamatan 3

- Rata - rata nilai setelah perbaikan adalah 56.08 dengan standard deviasi 12.47891 dengan jumlah pengamatan 3 
Grafik 5 analisa debit aliran in (masuk) pada pompa, saringan dan kecepatan L.O

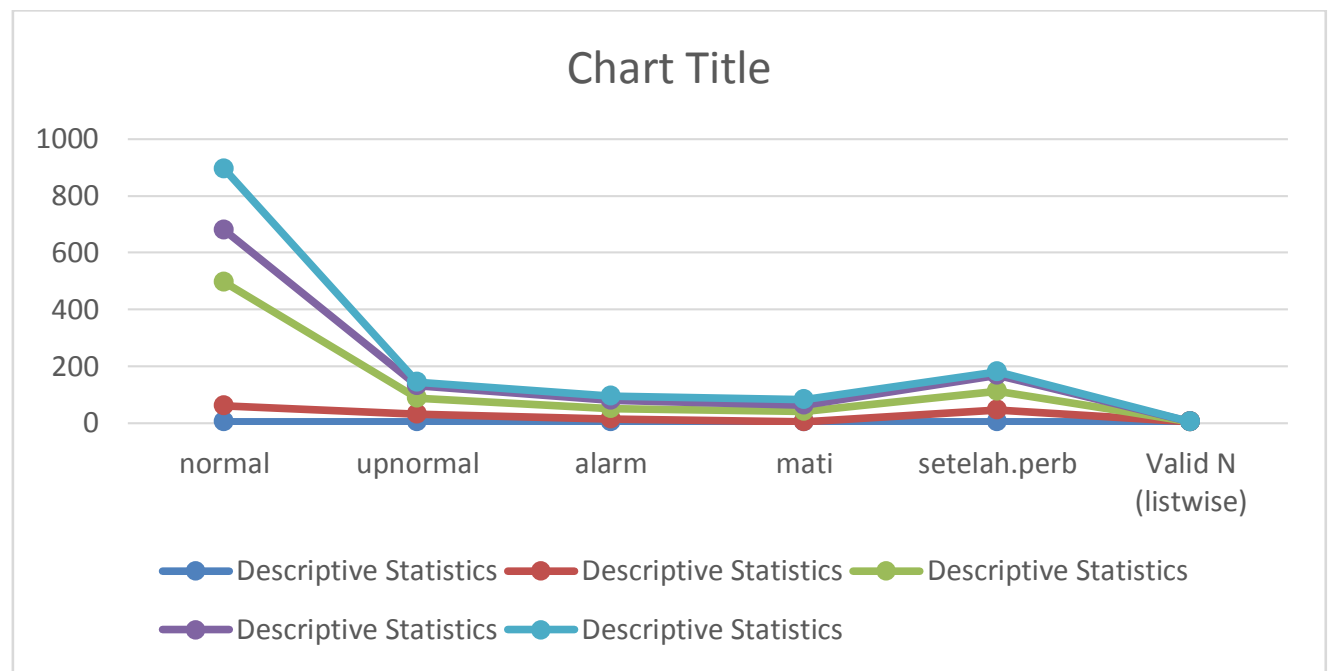

f. Analisa data debit aliran out Pompa ,Saringan dan kecepatan L.O

Tabel 6 analisa debit aliran out (keluar) pada pompa , saringan dan kecepatan L.O

\section{Descriptive Statistics}

\begin{tabular}{|l|c|c|c|c|c|}
\hline & $\mathrm{N}$ & Minimum & Maximum & Mean & Std. Deviation \\
\hline Normal & 3 & 49.10 & 69.00 & 61.6000 & 10.88623 \\
Upnormal & 3 & 33.30 & 64.30 & 49.0667 & 15.50688 \\
Alarm & 3 & 12.00 & 40.50 & 31.0000 & 16.45448 \\
Mati & 3 & 1.20 & 40.40 & 27.3333 & 22.63213 \\
setelah.perb & 3 & 48.80 & 76.70 & 64.5000 & 14.27550 \\
Valid N & 3 & & & & \\
(listwise) & & & & & \\
\hline
\end{tabular}

Sumber : hasil proses olah data dengan program spss -2018 
Penjelasan :

- Rata - rata nilai normal adalah 61.60 dengan standard deviasi 10.88623 dengan jumlah pengamatan 3

- Rata -rata nilai upnormal adalah 49.0667 dengan standard deviasi 15.50688 dengan jumlah pengamatan 3

- Rata - rata nilai alarm adalah31.00 dengan standard deviasi 16.45448 dengan jumlah pengamatan 3

- Rata - rata nilai mati adalah 27.33 dengan standard deviasi 22.63213 dengan jumlah pengamatan 3

- Rata - rata nilai setelah perbaikan adalah 64.50 dengan standard deviasi 14.27550 dengan jumlah pengamatan 3

Grafik 6 analisa debit aliran out (keluar) pada pompa, saringan dan kecepatan L.O

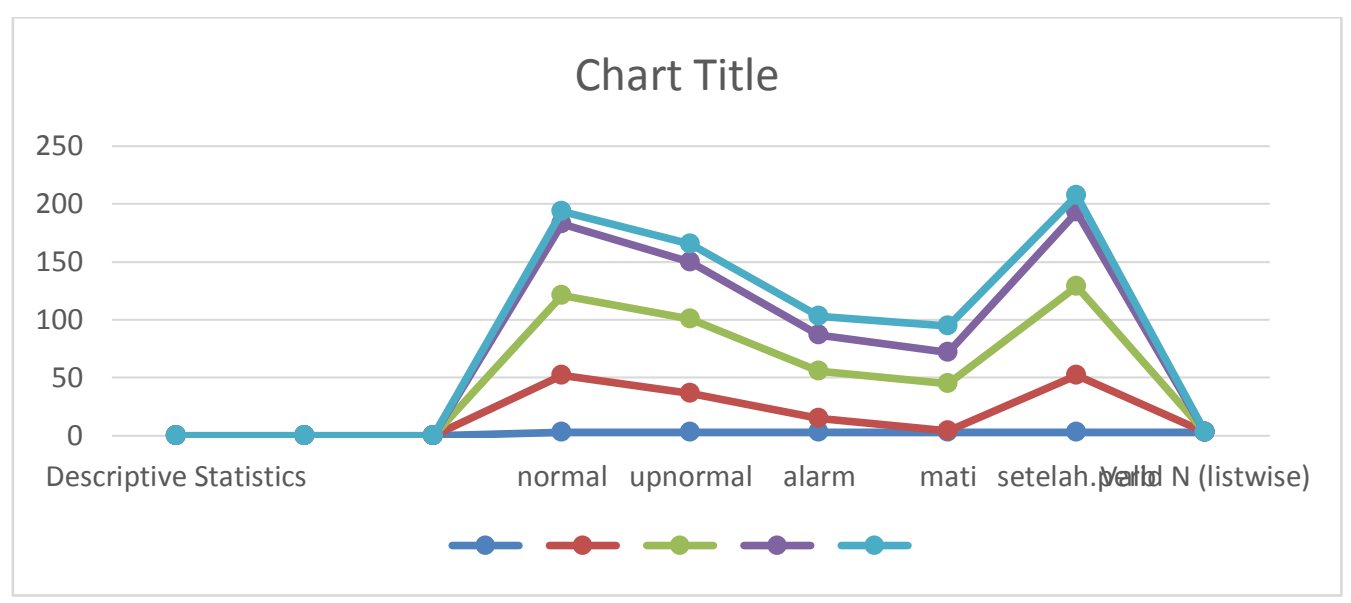

1. dengan formula rumus

Untuk melakukan pembahasan data hasil perhitungan harus sesuai dengan yang telah di tetapkan sebagai acuan pembahasan data penelitian,sebagai dugaan sekaligus kenyataan selama melakukan pengamatan langsung dilapangan yaitu kurang pengaruh kandungan minyak lumas terhadap kerataan main bearing main main engine pada kapal,disebabkan oleh bagian pompa yang mengalami kerusakan. 
Dengan demikian dilakukan perhitungan untuk memperoleh nilai perbandingan yang sebenarnya,yaitu :

a. Data hasil pengamatan saat pompa hydraulic beroperasi dalam keadaan normal.

a) Perhitungan jumlah tekanan pompa

Berdasarkan pengambilan data diatas, untuk mengetahui terjadinya penurunan tekanan pada pompa, dengan menggunakan rumus sebagai berikut :

$\mathrm{P}=\mathrm{n} /$ Qact

$\mathrm{P}=$ tekanan

$\mathrm{n}=$ putaran pompa

Qact $=$ debit aliran $\mathrm{cm}^{2} / \mathrm{s}$

Diketahui :

$\mathrm{P}=\mathrm{n} / \mathrm{Q}_{\mathrm{act}}$

$P=1800 / 60$

$\mathrm{P}=30$

b) Perhitungan debit aliran

Qact $=\mathrm{n} / \mathrm{P}$

Dimana :

Qact : debit aliran $\mathrm{cm}^{2} / \mathrm{s}$

n : putaran pompa

$\mathrm{P}$ : tekanan

Diketahui :

Qact $=\mathrm{n} / \mathrm{P}$

$$
=1800 / 30
$$

Qact $=60 \mathrm{~m}^{3} / \mathrm{s}$

b. Data hasil pengamatan saat pompa beroperasi dalam keadaan upnormal.

1. Perhitungan jumlah tekanan pompa

Diketahui : 


$$
\begin{aligned}
P & =n / Q \\
& =1800 / 70 \\
P & =25.7 \mathrm{~kg} / \mathrm{cm}^{2}
\end{aligned}
$$

2. Perhitungan debit aliran

$$
\begin{aligned}
\text { Qact } & =\mathrm{n} / \mathrm{P} \\
& =1800 / 54 \\
\text { Qact } & =29.4 \mathrm{~m}^{3} / \mathrm{s}
\end{aligned}
$$

c. Data hasil pengamatan pompa setelah perbaikan

1. Perhitungan jumlah tekanan pompa

Diketahui :

$$
\begin{aligned}
\mathrm{P} & =\mathrm{n} / \text { Qact } \\
& =1808 / 62.00 \\
\mathrm{P} & =30 \mathrm{~kg} / \mathrm{cm}^{2}
\end{aligned}
$$

2. perhitungan debit aliran

$$
\begin{aligned}
\text { Qact } & =\mathrm{n} / \mathrm{P} \\
& =1808 / 30 \\
\text { Qact } & =60.2 \mathrm{~m}^{3} / \mathrm{s}
\end{aligned}
$$

d. Data hasil pengamatan saat alarm

1. perhitungan jumlah tekanan pompa

Diketahui :

$$
\begin{aligned}
P & =n / \text { Qact } \\
& =1800 / 180 \\
P & =10 \mathrm{~kg} / \mathrm{cm}^{2}
\end{aligned}
$$

2. perhitungan debit aliran

$$
\begin{aligned}
\text { Qact } & =\mathrm{n} / \mathrm{P} \\
& =1800 / 54 \\
\text { Qact } & =33.3 \mathrm{~m}^{3} / \mathrm{s}
\end{aligned}
$$

e. Data hasil pengamatan saat mati

1. perhitungan tekanan pompa

Diketahui :

$$
\mathrm{P}=\mathrm{n} / \text { Qact }
$$




$$
\begin{aligned}
& =1800 / 5.92 \\
& =9.7 \mathrm{~kg} / \mathrm{cm}^{2}
\end{aligned}
$$

c) perhitungan debi aliran

$$
\begin{aligned}
\text { Qact } & =\mathrm{n} / \mathrm{P} \\
& =1800 / 59 \\
& =30 \mathrm{~m}^{3} / \mathrm{s}
\end{aligned}
$$

d) Analisa hasil perhitungan

a. Tabel 7 Perhitungan rumus dari pompa , saringan dan kecepatan L.O

\begin{tabular}{|c|c|c|}
\hline \multicolumn{3}{|c|}{ Tekanan dan debit aliran pompa } \\
\hline Kondisi & $\begin{array}{c}\text { Tekanan } \\
\left(\mathrm{kg} / \mathrm{cm}^{2}\right)\end{array}$ & $\begin{array}{c}\text { Debit aliran } \\
\left(\mathrm{m}^{3 /} \mathrm{s}\right)\end{array}$ \\
\hline Normal & 30 & 60 \\
\hline Upnormal & 29 & 42.6 \\
\hline Alarm & 16 & 33.3 \\
\hline Mati & 10 & 30 \\
\hline Setelah perbaikan & 30 & 60.2 \\
\hline
\end{tabular}

Sumber : engine room Mv. Bni castor

b. tabel 8 hasil perhitungan rumus dari pompa, saringan dan kecepatan L.O menggunakan program spss 


\section{Descriptive Statistics}

\begin{tabular}{|l|c|c|c|c|c|}
\hline & $\mathrm{N}$ & Minimum & Maximum & Mean & $\begin{array}{c}\text { Std. } \\
\text { Deviation }\end{array}$ \\
\hline pres.normal & 1 & 30.00 & 30.00 & 30.0000 &. \\
pres.ubnormal & 1 & 29.00 & 29.00 & 29.0000 &. \\
pres.stelah.p & 1 & 30.00 & 30.00 & 30.0000 &. \\
deb.aliran.normal & 1 & 60.00 & 60.00 & 60.0000 &. \\
deb.aliran.ubnormal & 1 & 29.40 & 29.40 & 29.4000 &. \\
deb.aliran.stelah.p & 1 & 60.20 & 60.20 & 60.2000 &. \\
Valid N (listwise) & 1 & & & & \\
\hline
\end{tabular}

Sumber : hasil proses olah data dengan program spss -2018

c. grafik 7 hasil perhitungan

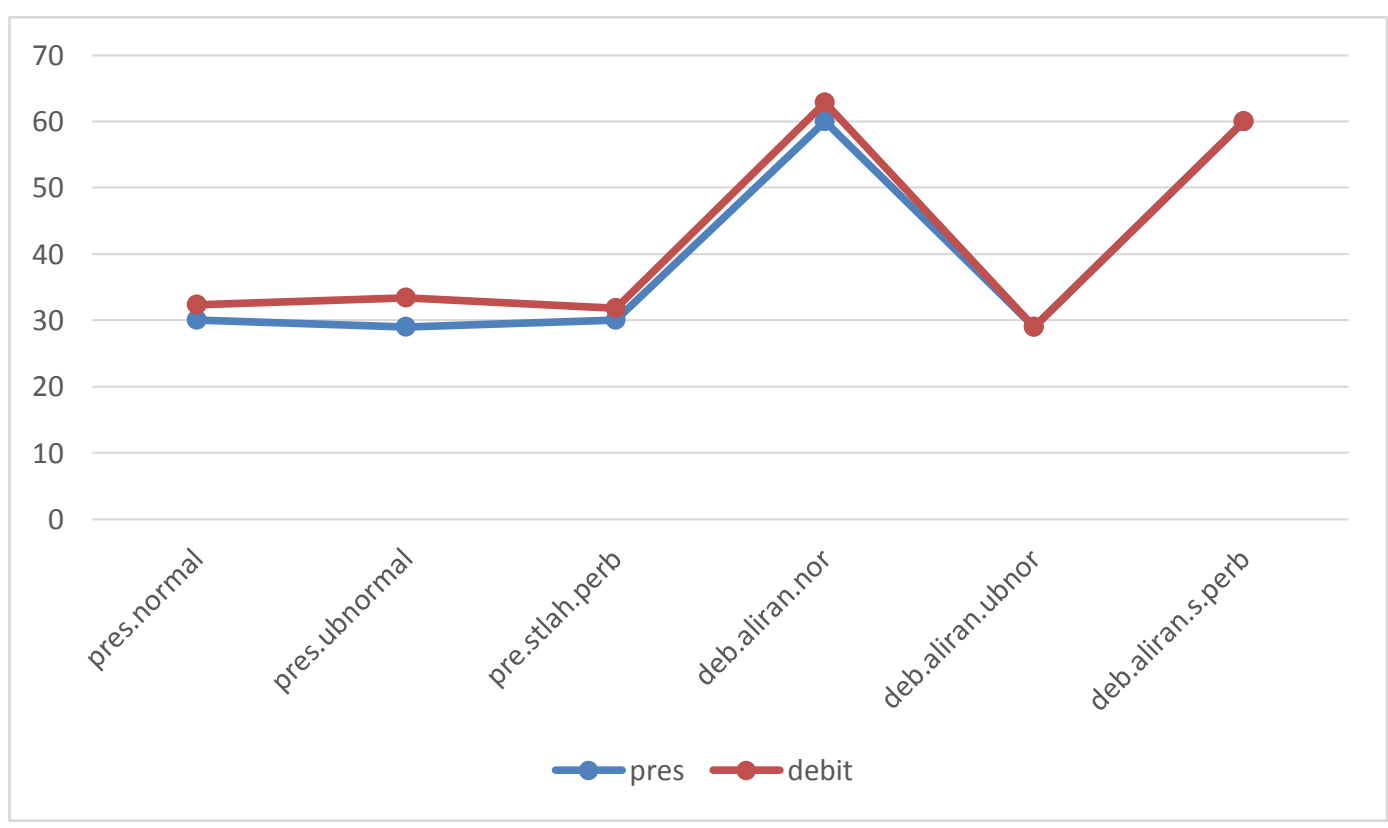

\section{Pembahasan Hasil Penelitian}

Adapun pemeriksaan yang dilakukan terhadap system sebagai analisis dari permasalahan tidak ratanya main bearing adalah sebagai berikut

1. pembahasan hasil penelitian

a. Kebocoran pada system pelumasan. 
Hasil analisa spss menunjukkan bahwa nilal tekanan yang di peroleh untuk tekanan L.O pada saat mesin mati sebesar : 5.92 $\mathrm{kg} / \mathrm{cm}^{2}$ angka ini sangat mempengaruhi system pelumasan yaitu, kinerja mian tidak stabil.

b. kerusakan pada pompa.

Hasil analisa spss menunjukkan bahwa nilai tekanan dan debit aliran L.O yang keluar pada pompa sebesar $5.92 \mathrm{~kg} / \mathrm{cm}^{2}$ dan $23.90 \mathrm{~m} /$ detik.nilai ini sangat mempengaruhi kinerja main engine

2. Penanganan

a. untuk mengembalikan tekanan $5.92 \mathrm{~kg} / \mathrm{cm}^{2}$ dan debit aliran 23.90 $\mathrm{m} /$ detik ke keadaan normal, perlu dilakukan pendataan tentang bagian-bagian pada :

1. Semua system pelumasan

2. Pompa

3. Solusi

a. semua bagian yang sudah di periksa dengan detail dan di temukan kebocoran harus diganti yang baru

b. pompa yang sudah di periksa dan di teliti dan di temukan roda gigi yang bermasalah yaitu aus, sehingga harus di ganti yang baru.

\section{PENUTUP}

a. Kesimpulan

1. Karena kurangnya penanganan atau perawatan pada bantalan utama dan akhirnya menyebabkan daya kerja bantalan tidak maksimal dalam menjaga tingkat keseimbangan putaran poros.

2. Kurangnya perhatian pada pemakaian jam kerja pada komponen mesin khususnya bantalan utama, maka kerusakan tidak dapat dihindari dan akan menyebabkan kerusakan baru akibat pengaruh dari komponen-komponen yang seharusnya sudah diganti tetapi tidak diganti. 
3. Kurangnya perhatian terhadap kekentalan minyak lumas sehingga menyebabkan pelumasan tidak berjalan dengan baik dan meyebabkan goresan pada main bearing.

b. Saran

1. Selalu memperhatikan jam kerja (running hours) pada bantalan utama mesin induk yang ditentukan pabrik pembuat.

2. Selalu melakukan pengukuran Jumlah minyak lumas yang melumasi bagian mesin di dalam carter sehingga kondisi minyak lumas dapat di kontrol jumlahnya dan kekentelannya

3. Gantilah minyak lumasnya sesuai dengan spesifikasi yang ditentukan pabrik pembuat.

\section{DAFTAR PUSTAKA}

[1]. P. Van Maanen,. Motor Diesel Kapal Jilid 1 Nautech.

[2]. Robert L . Mott, P.E., 2004. Elemen-Elemen Mesin dan perancangan Mekanis By person education.

[3]. Sularso., Kiyokatsu suga., Dasar Perencanaan dan pemilihan Elemen Mesin.

[4]. S.H Frederik dan H. Capper., 1976 Materials For Marchinery

[5]. V,L. Maleev M, E, - Dr.AM, 1986. Operasi dan Pemeliharaan Mesin Diesel.

[6]. Rizqon fajar dan Siti Yubaidah, 2017 Penentuan Kualitas Pelumasan Mesin

[7]. M.arisandi., Darmanto., Priangkoso, M., 2012. Analisa Pengaruh Bahan Dasar Pelumas Terhadap Viskositas Pelumas Dan Konsumsi Bahan Bakar

[8]. Prasetya Sigit S., Astriawati, N., Purjiyono., 2019. Perawatan Sistem Pelumasan Mesin Utama 